\author{
EWA HÜBNER \\ Uniwersytet Wrocławski
}

\title{
Wypisywanie życia. Etnograficzne spotkanie z Walerią Prochownik - pisarką z żywieckiego Sporysza
}

\section{Wprowadzenie}

Doznać świat drugiego człowieka - przewodnia myśl, która zrodziła się pod1 czas mojego pierwszego etnograficznego wyjazdu terenowego - w ogromnej mierze wyznaczyła charakter przyszłych etnologicznych poszukiwań. Spotkanie z Walerią Prochownik zaowocowało trwalszą znajomością, dzięki której stopniowo dążyłyśmy do tego, by - jak pisze Paul Rabinow (2010: 57) - „pojawiła się wzajemnie konstruowana podstawa doświadczenia i rozumienia, królestwo słabego i niepewnego zdrowego rozsądku, który stale ulegał załamaniu, łataniu, ponownemu badaniu, najpierw tu, potem tam".

Początkowym celem mojego wyjazdu na Żywiecczyznę (maj 2013 r.) były spotkania z ludźmi, którzy tworzą współczesne opowieści legendarne lub kontynuują tradycję przekazu legend dawnych. Chciałam doświadczyć tego, jak oni żyją, w jaki sposób opowiadają, a przede wszystkim dlaczego to robią - jakie znaczenie mają dla nich wspomniane historie, ich kreowanie, spisywanie i dzielenie się nimi. Pierwsze rozmowy zarysowały przede mną szerszy kontekst życia w Sporyszu (obecnie dzielnica Żywca) oraz umożliwiły spotkanie z Walerią Prochownik, na które umówiłyśmy się telefonicznie. Następnego dnia, zaraz po wzajemnym przedstawieniu, zostałam obdarowana jej opowieścią, co nakierowało moje etnograficzne poszukiwania na nieco inny niż planowany tor.

Pani Waleria, przez wiele osób nazywana "gawędziarką" i „poetką", sama siebie określa mianem "typowego twórcy ludowego"1 lub „twórcy ludowego z krwi i kości” - „bez żadnych naleciałości”. Uważa również, że jest pisarką: „nie chcę się robić poetką. Możliwe, że tam coś z poezji jest, ale też mi się wydaje, że za bardzo szafujemy tym słowem "poeta»". Choć Donat Niewiadomski (2011) precyzyjnie charakteryzuje jej twórczość, nasze początkowe rozmowy szybko

\footnotetext{
1 Wszystkie poniższe cytaty, które nie są oznaczone przypisem, stanowią słowa Walerii Prochownik.
} 
ujawniły, że autorka nie lubi szczegółowo klasyfikować własnych utworów i przyporządkowywać ich do konkretnego gatunku. Wszystkie swoje teksty mówione i czytane traktuje jako całość - pisarstwo. I to właśnie pisarstwo uczyniłyśmy wiodącym tematem naszych rozmów, toczonych na przestrzeni dwóch lat znajomości ${ }^{2}$. Podstawowym celem tych poszukiwań, wyznaczającym także kierunek niniejszego tekstu, było odpowiedzenie na pytanie: czym jest pisarstwo dla Walerii Prochownik?

W czasie pierwszych spotkań, najczęściej popołudniami, zasiadałyśmy przy kuchennym stole - towarzyskim centrum domu pisarki - gdzie do późnych godzin zanurzałyśmy się w świecie opowieści. Nie tylko literackich, które czytała bądź recytowała podczas rozmów, lecz przede wszystkim opowieści o własnych losach, myślach, dylematach, odczuciach czy potrzebach. Starałam się, aby moje pytania były odpowiedzią na jej słowa; by to ona nakreślała obszar znaczących dla niej zagadnień czy historii, które potem uczyniłyśmy przedmiotem głębszych rozmyślań.

$Z$ biegiem czasu nasza relacja zmieniała się. $W$ moim odczuciu pisarka coraz rzadziej zastanawiała się, czy - jak to ujmowała - jej „twarde myśli” na coś mi się przydadzą. Równocześnie sama uwalniałam się od poczucia, że zawsze powinnam mieć $\mathrm{w}$ zanadrzu kolejne pytanie, które świadczyłoby o moim uważnym wsłuchaniu w jej słowa i tłumaczyłoby sens moich wizyt. W trakcie następnych rozmów nie próbowałyśmy już sprostać wyimaginowanym - a może także realnym - wzajemnym oczekiwaniom. Rozmawiałyśmy, swobodnie wymieniając poglądy, historie oraz wątpliwości. Wielość podejmowanych wątków nie oddalała nas jednak od zasadniczego tematu badań, ponieważ w świecie Pani Walerii nie ma wyraźnego podziału na sferę pisarską i... jakąkolwiek inną, którą mogłabym jednoznacznie wyodrębnić. Sprawy codzienne czy pozornie od pisarstwa odległe w ostateczności okazywały się być z nim ściśle powiązane.

Podczas kolejnych spotkań podzieliłam się z Panią Walerią moim rozumieniem „etnografii opartej na współpracy”, którą zdecydowałyśmy się wspólnie i na swój sposób realizować (Lassiter 2005; Pietrowiak 2014; Rappaport 2013; Wyka 1993). Jej efektem miała stać się praca licencjacka wzbogacona o komentarz pisarki. Wspólnie omawiałyśmy również raporty $\mathrm{z}$ badań, które pisałam $\mathrm{w}$ ramach zajęć z metodyki etnograficznych badań terenowych. W ten sposób konfrontowałyśmy wzajemne interpretacje naszych wcześniejszych rozmyślań oraz rozszerzałyśmy je o nowe wątki wspólnych rozważań (zob. Lassiter 2005; Wyka 1993: 38-39, 60-61). Równocześnie starałyśmy się wyznaczyć granicę opisywanych zagadnień, która pozwoliłaby zachować sferę prywatności pisarki i wskazać, którymi historiami nie chce dzielić się z innymi odbiorcami.

W moim odczuciu decyzja o realizowaniu etnograficznej współpracy wypłynęła ze specyfiki sporyskich spotkań (zob. Wyka 1993: 29), przede wszystkim

2 Spotkałyśmy się: 15-16 i 18-19.05.2013 r.; 4-6 i 8-9.04.2014 r.; 13-14.12.2014 r.; 7-8.02.2015 r.; 17-19.07.2015 r.; 20-21.08.2015 r. Uzupełnieniem były również rozmowy telefoniczne i korespondencja listowna. 
ze wspólnie podjętego tematu oraz wzajemnej otwartości na odmienny sposób postrzegania i rozumienia. Nie uważam, że metoda ta - jak według Luke'a Erica Lassitera często przekonują jej przeciwnicy - „prowadzi do banalnego i jałowego poznawczo kompromisu" (zob. Pietrowiak 2014: 32), lecz przeciwnie - poszerza przestrzeń dialogu pomiędzy uczestnikami badań, o pole, które dla samego podejścia dialogicznego pozostaje zamknięte. Ponadto nie narzuca ona konieczności wypracowania wspólnego stanowiska uczestników badań, ale stwarza możliwość konfrontacji wniosków badacza z oceną (również krytyczną) partnera rozmów.

W trakcie dalszych spotkań rozpatrywałyśmy poglądy i kategoryzacje dotyczące ogólnie pojętego pisarstwa, sformułowane przez różnego rodzaju badaczy. Przedstawiałam rozmówczyni wypowiedzi filozofów, historyków, etnologów czy pisarzy, które na rozmaity sposób korespondowały z naszymi wcześniejszymi rozmowami. Prosiłam pisarkę o odniesienie się do zaproponowanych przeze mnie myśli oraz wyrażałam własne rozumienie jej słów i naukowych rozważań.

Poniżej przybliżę efekty rozmów z Panią Walerią oraz proces wypracowywania wspólnej płaszczyzny rozumienia. Ukażę je z perspektywy moich doświadczeń, co wynika z osobistego poglądu, że - jak dowodzi Clifford Geertz (2003: 44-46) - całkowite wyzbycie się subiektywizmu w żadnym etnograficznym poznawaniu drugiego człowieka nie jest możliwe.

\section{Sporysz - specyfika miejsca}

Sporysz to obecnie jedna z południowo-wschodnich dzielnic Żywca, zamieszkana przez górali żywieckich, którzy stworzyli własną gwarę, ukształtowaną pod wpływem "słownictwa osadników wołoskich i mowy śląskiej" (Futoma, Cebrat 2006). Do 1950 r. stanowił odrębną wieś (zob. Figiel i in. 2006: 436), lecz według Pani Walerii miejskie wpływy szerzej uwidoczniły się dopiero w latach 70. XX wieku. Jak twierdzi, najoporniej przebiegały zmiany $\mathrm{w}$ mentalności mieszkańców. Trudne do wykorzenienia okazało się na przykład przeświadczenie, że „dziewczynie nie można nic, a mężczyźnie wszystko".

Górski obszar Żywca stanowił niegdyś podatny grunt do powstawania tajemniczych - a co za tym idzie - atrakcyjnych w odbiorze opowieści. W XVI-wiecznych Karpatach, na pograniczu państwa polskiego, węgierskiego i czeskiego - a więc w okolicach dzisiejszego Żywca - grasowały liczne bandy zbójów, których życie stopniowo przybierało formę protestu przeciw wyzyskowi władzy. Zbójeckie poczucie wolności, związane z wyrwaniem się spod zależności feudalnych, wzbudzało podziw i rozniecało marzenia miejscowych górali. $Z$ tego względu w XVII i XVIII wieku w lokalnych tradycjach zaczęły się rodzić rozmaite legendy (zob. Kastelik-Herbuś 2007; Młodzianowski 2009-2012), które kształtowały się przez kolejne stulecia; niektóre z nich przetrwały do dziś przede wszystkim za sprawą przekazu ustnego. Temat zbójnictwa wielokrotnie podejmowała 
również Pani Waleria, próbując - zazwyczaj poprzez pisanie gawęd - zrozumieć losy dawnych harnasi.

Przed spotkaniem z pisarką okoliczni mieszkańcy mówili mi o coraz większym rozluźnieniu kontaktów międzyludzkich w Żywcu. Tłumaczyli, że zjawisko przybrało na sile w ciągu ostatnich dziesięcioleci, co - jak mówił Mariusz $\mathrm{Kąkol}^{3}$ - wynikało z tego, że „ludzie łodeszli łod gospodorki i poszli robić we fabrykach". Wcześniej sąsiedzi spotykali się przy darciu pierza czy świniobiciu, a ponieważ - dodał rozmówca - „nie było prądu, telewizora, no to siadali ludzie, starzy przychodzili i opowiadali o byle jakich rzecach: ło diabłach, ło strzygach, ło urokach". Według Pani Walerii opowieści straciły swoją powszechność również za sprawą przekazu gwarowego, który wychodząc stopniowo z użycia, "umierał tą swoją śmiercią naturalną". Takimi historiami „interesują się tylko dzieci z tych wiosek tutaj, gdzie w domach rodzice mówią jeszcze gwarą". Według pisarki

można powiedzieć, że kto zna gwarę, to tak w połowie jakby znał obcy język. Bo to nie tylko wyrazy są inne, ale fonia głosu, to jest coś specyficznego (...). To trzeba wypić z mlekiem matki (...). Kto tak nie zna tutejszych terenów, nie ma tak $\mathrm{z}$ gwarą do czynienia, to bardzo trudno mu się jej nauczyć.

Pani Waleria sama używa nie tylko języka lokalnego, ale płynnie przechodzi także do mowy i pisma niegwarowego. Moi rozmówcy jednogłośnie twierdzili, że w tym względzie zarysowuje się wyraźna różnica między Żywcem a okalającymi go wsiami, które są jeszcze ostoją słownej tradycji. Niejednokrotnie do tej drugiej grupy częściowo zaliczali również Sporysz, który w ich pamięci zachował się jako teren wiejski.

\section{Waleria Prochownik}

Pani Waleria urodziła się w 1943 r. Całe życie mieszka w Sporyszu. Zaczęła pisać już jako dziecko. Gdy w audycji radiowej Podwieczorek przy mikrofonie usłyszała "na żywo głos Gałczyńskiego", a w odpowiedzi na jego słowa równie „żywą reakcję publiczności", postanowiła, że będzie prezentować swoje utwory na scenie: „Owce szłam paść, a w podomce, w kieszeni miałam ołówek czy długopis, no i zeszyt (...). Gdyby to wykazywała takie umiejętności dziewczyna z Żywca, to nauczyciele może by się nią interesowali. Mną się nie interesował nikt".

Lata młodości pisarki mocno wyznaczyła ciężka choroba mamy. W tych czasach

gdy baba robiła chłopską robotę, to mogło być. On babskiej roboty się nie chytał (...). Dawniej po wsiach bywało, że mężczyźni do domowych prac to kompletnie

\footnotetext{
3 Muzyk, twórca legend i współtwórca Zbójnickiej Kompanii, pochodzący z Cięciny. Rozmowa przeprowadzona w $2013 \mathrm{r}$.
} 
mieli takie ręce, że nic nie potrafili zrobić sobie. A tata mój za bardzo się nie brał, on tam był zaabsorbowany więcej sobą. Tak, że ja musiałam za tę mamę być. I gotować, i popierać, i jeszcze do tego mieliśmy takie hektarowe gospodarstwo, krowa była. I to wszystko na mojej głowie [ponieważ w domu oprócz dwóch braci mieszkała młodsza siostra]. (...) Nie na darmo się gadało, że kobieta w chałpie trzy węgły, trzy rogi trzyma, a chłop ino jeden. Jak się chłopiec urodził, to było ojejku, jak dziewczę to nie, bo to jest kłopot. A dziewczę wydać... Dziurę gnoja ${ }^{4}$ łod chałpy wywieść to na jedno - kłopotu się pozbyć, marasu ${ }^{5}$. Takie panowało przeświadczenie i taki był ten pieterny ${ }^{6}$ babski żywot.

Pani Waleria ukończyła siedem klas szkoły podstawowej. Sprawy rodzinne nie pozwoliły jej na dalszą edukację, dlatego wiele razy podkreślała, że w dziedzinie pisarstwa jest „samoukiem”. Porzuciła swoją pasję na blisko 20 lat. Zaczęła prowadzić z mężem gospodarstwo rolne. Ciężka praca nie zaspokajała jednak jej ambicji. Czuła się niespełniona: „czegoś mi w życiu brakowało. O czymś marzyłam. Jeszcze nie wiedziałam o czym".

Pewnego razu podczas grabienia siana zobaczyła w wyobraźni pegaza, który dopytywał: „Dlaczego się poddałaś i nic nie robisz?”. Ze zdziwieniem wyjaśniła, że przecież pracuje w polu, zajmuje się zwierzętami, ma czworo dzieci... „I ja nic nie robię?!” - zapytała. „Zapomniałaś, że nie samym chlebem się żyje” - usłyszała w odpowiedzi. „Poczułam jakby mi zasłona z oczu spadła. Po przyjściu z pola od razu coś napisałam" - wspominała z uśmiechem. Zaczęła od wierszy: „gdzie jakby zamknięty rozdział mojego życia jest - kiedy pracowałam w polu i [pisałam] nawet o polnej drodze, o sianokosach, o żniwach. Starałam się w poezji uwiecznić te czynności tak bardzo przyziemne". Przeszkodę w realizacji pasji prócz natłoku pracy - stanowił jednak nieprzychylny stosunek męża do takiego "marnowania czasu". Przez rok tworzyła w ukryciu, mając poczucie funkcjonowania w dwóch rzeczywistościach. Był „świat realny”, przeznaczony dla "zahukanej wiejskiej kobiety", oraz „świat myślowy", który stanowił odskocznię od codzienności, a jednocześnie zachęcał do jej literackiego opisu. Jak mówiła: "każdego dnia najpierw chodziłam po stajni i robiłam swoje, a zanim się do obiadu siadało, to musiałam wykroić trochę czasu na pisanie, co odbywało się kosztem niepomytych garów, czegoś niezrobionego". Każdy członek rodziny równo pracował na roli ",a to, co w domu, to się nie liczyło". Tego typu obowiązki należały tylko do niej.

Do dziś pamięta słowa recenzji pierwszych prób poetyckich w „Zielonym Sztandarze":

Pani wiersze są poprawne formalnie, choć można mieć zastrzeżenia do zbyt banalnych, powtarzających się środków wyrazu. Ale przede wszystkim są zbyt

\footnotetext{
4 Dziura gnoja - gwar. gnojowisko.

5 Maras, marasy - gwar. błoto, mokradła (Gąsiorek, Juraszek 2011: 63).

6 Pieterne - gwar. trudne do wykonania, uciążliwe (Gąsiorek, Juraszek 2011: 91).
} 
werbalne, zbyt deklaratywne, jak gdyby opowiedziane do końca. Siłą poezji jest chęć sięgnięcia ponownie po wiersz. Nie odczułam jej po lekturze Pani wierszy.

Po zapoznaniu się z tymi słowami ",ta gazeta to poleciała w kąt". Po chwili zastanowienia początkująca pisarka podniosła druk z ziemi. Spojrzała na własny tekst, potem ponownie na jego ocenę i zaczęła się śmiać. Pokornie przyznała rację recenzentce. To wydarzenie pozwoliło jej na inny ogląd własnego pisarstwa. Kolejny jej wiersz zamieszczono w następnym wydaniu tego samego tygodnika już bez żadnych zastrzeżeń.

Po prezentacji własnych utworów w Grupie Literackiej "Gronie” zaczęła tworzyć jawnie. Jej decyzja nie spotkała się z sąsiedzkim zrozumieniem. Całe otoczenie trochę się z niej naśmiewało. Pisała wiersze „dla męża”, lecz ujmowała w nich przede wszystkim swoją „zależność” od niego. Potem „dał mi tak w kość, że nie było sensu" - wspominała. Powoli odchodziła od poetyckiej formy tekstów, by odnaleźć się w języku innego rodzaju opowieści. Jako gawędziarka zadebiutowała na scenie w wieku 42 lat. Jak tłumaczyła:

Zaczęło mi w tych wierszach być za ciasno. Bo to jakby takie pewne ograniczenie daje, a moja wybujała wyobraźnia leciała gdzieś dalej (...). [W większości] poezja do ludzi stąd nie przemawia. Poezja jest do ludzi, którzy więcej myślą, mają ten umysł jakoś bardziej rozwinięty. A tutaj to życie jest za twarde, ono nie sprzyja jakimś głębszym przemyśleniom (...). Mnie zależy, żeby ten odbiorca wiedział o czym ja mówię, żeby coś z tego wynosił.

Równocześnie nigdy całkowicie nie porzuciła poezji. Nadal dostrzega ją wszędzie: „Ja nieraz sobie myślałam: po co? Nie będę wierszy pisać. Ale one same wychodzą". Niejednokrotnie pretekstem do ich powstania czyni zdarzenia krótkie i z pozoru błahe (Prochownik, Ostatnie słowo do rozbitej szklanki po winie):

Z brzękiem zakończyłaś życie kolorowe.

Zmienna i niestała, chociaż krucha istoto.

(Buty ciągle nosząc na wysokiej szpilce, włosy przepasane cienką wstążką złotą).

Wspominając, zbieram okruchy rozkoszy.

Rocznik ten a ten, kolor purpurowy,

krew wulkanem kipi, w mózgu chęć do czynu,

który teraz mi w palcach cichuteńko skrzypi.

Wiem, wiem, że ty byłaś aż nadto pieszczona,

te pocałunki liczone na kopy.

Niejeden twym czarem boskim napojony

świat cały z rozmachem rzucał ci pod stopy.

Film się urywa.

Z wyżyn spadasz na kolana.

Wołasz: pokuty!

A wszystko to jest bańka mydlana. 
Jak zatem udało jej się pogodzić życie w tutejszym - „niesprzyjającym głębszym przemyśleniom" - klimacie z pisaniem wierszy? Pomimo częstego kontaktu z innymi ludźmi - głównie za sprawą konkursów gawędziarskich czy wystąpień okolicznościowych - wybrała życie nieco na uboczu i świat swoich opowieści. Na ojcowiźnie męża „nigdy tu z nikim nie miałam wspólnego języka” - stwierdziła. Prócz odwiedzin „po mleko czy jajko” nie czuła potrzeby, „żeby iść, posiedzieć, z kimś porozmawiać; tak jak się kiedyś chodziło na plotki".

Sukcesy w konkursach ${ }^{7}$ nie poprawiły nastawienia rodziny i sąsiadów do jej pisarskiej pasji. Mężowi nie podobało się, że żona przestaje być od niego zależna. Dodatkowo zmagała się z innymi, dotkliwymi przeszkodami, o których nie chce opowiadać szerszemu gronu odbiorców: „Wystarczy, że ja się z tym całe życie męczę". Jednocześnie przekonywała:

Twórczość jest jakby publiczną spowiedzią. Chcąc nie chcąc, obnażamy stan swojej duszy, to, co myślimy, co nas nurtuje (...). Ale musimy wiedzieć jedno. Zawsze musi być ta granica. Nie wolno za bardzo się obnażać, bo to nikomu do niczego nie jest potrzebne i nikt tego nie zrozumie, bo to są nasze osobiste przeżycia.

Podobną myśl zawarła w utworze Przestroga:

(...) Nie rozdawaj siebie do ostatniej koszuli, bo ona bliższa ciału niż futrzana toga.

Nie wypruwaj żył na najbliższych żądania.

Nigdy nie zaspokoisz apetytu,

który rośnie w miarę jedzenia.

Gdy okazało się, że z pracy twórczej nie będzie miała emerytury, „wiedziałam, że ja już nie przestanę" - przekonywała z uśmiechem skromnej satysfakcji. Zazwyczaj zarabiała dzięki temu „parę złotych", jednak pisanie przynosiło jej głównie poczucie spełnienia i siłę: „przez to jakoś żem się uratowała. Bo tak to było nie do wytrzymania". Wielokrotnie miała dosyć tych zmagań. Mówiła sobie: „Za co i po co ty się bijesz?”. Za chwilę znów robiła swoje. Czasami utwory stanowią dla niej "„locysceni" ${ }^{8}$, jednak zapisany tekst nie sprawia, że problem znika - „zawsze coś pozostaje”. Powracając do pewnych wydarzeń czy przeżyć, próbuje rozprawić się z nimi poprzez zapis. Przykładem jest opowiadanie "Johanino krzywda" (Prochownik 2002), stanowiące próbę zadośćuczynienia za dziecięce wyśmiewanie się z kobiety, której cierpienie i ciężkie życie uświadomiła sobie dopiero po wielu latach.

\footnotetext{
7 Warto dodać, że osiągnięcia literackie zaowocowały w 2015 r. decyzją o przyznaniu pisarce Nagrody im. Oskara Kolberga (zob. Nagrody im. Oskara Kolberga "Za zastugi dla kultury ludowej" 2015).

8 Łocysceni - gwar. oczyszczenie.
} 
Myślę, że pisanie jest moim przeznaczeniem... I cieszę się, że pomimo takich różnych przeciwności losu tak jakby dopięłam swego. To jest chyba ważne, to się chyba liczy (...). Tak się bardzo boję, że gdyby na przykład życie moje było takie szczęśliwe, łatwe, a nie tak obarczone, takie ciężkie, to być może nie chwyciłabym się za pisanie... Może nie czułabym, że coś mi umyka. A to jednak chyba było potrzebne. Potrzebne były te moje zawirowania.

Według autorki nic nie dzieje się bez przyczyny, a czynników sprawczych należy upatrywać w „boskiej pomocy”. To, co inni nazywają talentem, dla niej stanowi „iskrę bożą", dlatego teraz spłaca "ten dług” i dziękuje Bogu, że przetrwała to wszystko. Jak przekonywała:

Ja do pewnego czasu miałam dwie osobowości, a teraz mam ten komfort, że mogę mieć tę jedną osobowość. One się splotły, nie muszą się kryć (...). Dopóki będę pisać, będę żyła. Gdy coś się stanie mi z głową - bo przecież różnie się może zdarzyć, nie jestem nieśmiertelna - to gdy przestanę pisać, bardzo szybko się mi śmiertnie.

\section{Hypomneumata: czym jest pisanie?}

Pani Waleria - jak mówiła - czerpie wiedzę ze wszystkiego, co ją otacza. Czyta wiele różnorodnych książek i czasopism. Nawet gazety, które uznaje za „marnej jakości", podsuwają jej pisarskie pomysły, ponieważ ukazują zjawiska w odmiennym świetle i pomagają rozróżnić wydarzenia realne od tego, co „naciągane". Gromadzi przemyślenia w pamięci lub nosi „w podświadomości”, czerpiąc z nich na bieżąco - pisze "jakby na żywo". Daleka jest od notowania cudzych sentencji. Chce mieć "sspokojne sumienie”. Jednocześnie nie ukrywa, że czasami inspiruje się pewnymi wątkami, na przykład ze starej, "około stuletniej” książki 100 baśni, zawierającej opowieści z całej Polski. Wybrany wątek nie stanowi jednak głównego przesłania jej tekstu, lecz jest on jedynie pewnym zaczątkiem, myślą, która zostaje rozwinięta $w$ inny, bogaty sposób, lub stanowi drobny epizod utworu.

Jak pisałam we wstępie, rozmawiałyśmy z Panią Walerią na temat filozoficznych i naukowych rozważań dotyczących natury pisma i pisarstwa. Wówczas okazało się, że "nie do przyjęcia” jest dla niej stanowisko Platona, który w Fajdrosie wyraża nieprzychylny stosunek do wynalazku pisma, jednocześnie gloryfikując mowę. Walter Ong (2003a: 369), podsumowując tę myśl filozofa, stwierdza wręcz, że "pismo (...) jest nieludzkie”.

Pani Waleria przekonuje, że zapisane przez nią opowieści „wypływają” z jej przemyśleń i jej "natury”: „Nigdy nie ma, żeby one były całkowicie wyssane z palca”; każda "oparta jest na prawdzie" i skrywa w sobie "kawałeczek życia”. Można w nich znaleźć nie tylko wątki autobiograficzne, refleksje, fragmenty osobiście usłyszanych rozmów czy inspiracje zaobserwowanymi wydarzeniami, ale także myśli dotyczące doświadczeń i wypowiedzi osób, o których słyszała od 
innych. W dużej mierze - choć nie wyłącznie - na bazie oralności powstają jej zapisywane historie, które nie służą jedynie do czytania - jak twierdzi, wszystkie jej utwory „można by było mówić”. Jednocześnie uważa, że "całkiem co innego jest mówić, a całkiem co innego jest pisać". W tym przypadku ma na myśli konkretnie mowę potoczną, z której czerpie inspiracje, zmieniając ją według własnych, literackich potrzeb. $W$ jej ocenie codzienne wypowiedzi cieszą się większą wolnością językową, ale „żeby to przelać na papier, to dwie różne sprawy”.

Jak sama zauważa, "słowa mówione są ulotne, do słów pisanych można wrócić", dlatego też z dużą ostrożnością traktuje to, co sama zapisuje. Stara się również unikać względnie „brzydkich” wyrazów. Jeśli tego typu określenia pojawiły się w zasłyszanych przez nią scenach, to na przykład „za «dupę» «zadek» można napisać". Jak dodaje „w tej ludowości «dupa», «gówno», to jest szczyt możliwości” użycia wulgaryzmów.

Zdaniem Pani Walerii niektóre zagadnienia determinują formę ich przekazu; na przykład historie o zbójnikach woli przedstawiać ustnie: „Gwarą lepiej mi się pisze dawne dzieje. W języku literackim niektóre rzeczy brzmiałyby sztucznie”. Jednocześnie pisarka wplata język gwarowy $\mathrm{w}$ opowieści o wydarzeniach współczesnych. Twierdzi przy tym, że „nie można pisać tak, jak to było w przekazach starych, tylko trzeba do współczesności trochę iść. Ale to trzeba robić z głową".

Stara się nadawać opowieściom ludzki wymiar. W odległych historiach o zbójnikach szuka "zwyczajnych ludzi” - ich realnych cech, prawdopodobnych problemów czy dylematów. Przed pisaniem o ich losach dużo czasu poświęca na poznanie kontekstu ówczesnych wydarzeń, dzięki czemu łatwiej zrozumieć motywacje niektórych harnasi i przeszkody, które napotykali. Jak mówiła: „nigdy nie piszę naprzód o tym, co się wydarzy, tylko o tym, co jest już jakby historią", którą osadza w realiach dawnego bądź współczesnego życia. Takie umiejscowienie stosuje również w opowieściach fikcyjnych, co - według niej - nadaje im pierwiastek prawdziwości. Stąd daleka jest od stwierdzenia, że pismo „istnieje w nierzeczywistym, nienaturalnym świecie" (Ong 2003a: 369). Wielokrotnie podkreślała, że pisanie było $\mathrm{w}$ przeszłości jednym $\mathrm{z}$ jej światów, w którym odzwierciedlenie znajdowały realne sprawy. Ostatecznie światy te scaliły się $\mathrm{i}$ teraz "żyje pisarstwem”. Nie zgadza się również z innym parafrazowanym przez Onga stwierdzeniem Platona, według którego pismo jedynie „udaje, że stawia poza umysłem to, co naprawdę może istnieć tylko w myśli" (Ong 2003a: 369). Jej zdaniem słowa potrafią odzwierciedlać przemyślenia, a dodatkowo ich zapis może dotrzeć do innych osób, wyjść poza rozum jednego człowieka, ponieważ zapisane historie na nowo odżywają w momencie ich czytania. Jak - w opozycji do słów Platona - pisze Ong (2003a: 369), mogą one zostać wskrzeszone „w nieograniczonych żywych kontekstach dzięki potencjalnie nieskończonej liczbie żywych czytelników”. Pani Waleria uważa, że „każdy inaczej odbiera” i interpretuje słowa, dlatego "trzeba być przygotowanym, że nie do wszystkich się dotrze". Jednocześnie twierdzi, że „im więcej ludzi dostrzega coś w utworze, tym on ma większą wartość". 
Na moje pytanie, czy pismo - jak dowodzi Ong - „oddziela poznającego od tego, co poznawane" (2003b: 199), odpowiedziała, że sama dystansuje się od niektórych ze swoich postaci, gdy nie zgadza się z ich negatywnym postępowaniem: „Są na przykład sytuacje, w których ja się mogę z kimś utożsamiać, ale bardzo rzadko kiedy, bo... «nikt nie powieli twojego ja, nie powieli życia na twoje podobieństwo»" (Prochownik, Przestroga). Choć jeśli oddzielenie to rozumieć jako barierę, przez którą piszący nie może doświadczać tego, co opisuje, to Pani Waleria zdecydowanie twierdzi, że

zanurza się człowiek [w tym, co opisywane], bo chcąc nie chcąc, to są przeżycia, to są emocje. Gdyby tego nie robił, to wówczas by głęboko nie myślał nad tym, co pisze. A gdy myśli, to musi zadawać sobie pytania: Boże, dlaczego on tak zrobił? Dlaczego on taki był? Dlaczego nie było to inaczej? (...) Ja w myśli dostosowuję się do toku jego myślenia, o ile to jest możliwe. Wiesz, może to jest tak, że on myśli całkiem inaczej, ale ja się ze wszystkich sił staram utożsamiać z tym człowiekiem. Czasem przeżywam te jego klęski. Chcąc pisać naprawdę sercem, to trzeba przeżywać, bo inaczej to będzie płytkie i nigdy nie odda tego, co się chce.

W Fajdrosie pojawia się kolejny zarzut wobec natury pisma:

(...) niepamięć w duszach ludzkich posieje, bo człowiek, który się tego wyuczy, przestanie ćwiczyć pamięć; zaufa pismu i będzie sobie przypominał wszystko z zewnątrz, ze znaków obcych jego istocie, a nie z własnego wnętrza, z siebie samego. Więc to nie jest lekarstwo na pamięć, tylko środek na przypominanie sobie (Platon 2000: 34).

Pani Waleria przyznaje, że ona także często „rzecz zapisaną automatycznie odsyła z pamięci”. Jednocześnie uważa, że „nigdy nie wolno pisać na siłę. Jeżeli teksty stawiają opór, jeżeli coś mi przeszkadza, to ja sobie daję spokój. Musi przyjść moment i wtedy piszę lekko. I bardzo często od razu znam na pamięć" co przekłada się m.in. na lepszą prezentację gawęd. Autorka zapisuje opowieści nie po to, by nie musieć ich pamiętać, lecz przeciwnie - by rozbudzić pamięć i wydobyć historie $z$ myśli w nowej, wypracowanej formie. Zapis jest dla niej również sposobem dzielenia się pamięcią $\mathrm{z}$ innymi. Często przywołuje $\mathrm{w}$ nim czasy czy osoby, które odeszły w powszechne zapomnienie - dzięki tekstom ożywają one podczas każdorazowej lektury.

Pisarstwo nie jest dla niej zwykłym środkiem na przypominanie sobie zdarzeń czy myśli. Zauważa, że niektóre z jej starszych utworów przedstawiają inne spojrzenie na świat. Zapisy wniosły coś nowego do jej świadomości i dzięki powracaniu do nich dostrzega rozwój swojej osobowości i postrzegania. Zdarza się, że po latach ten sam temat $w$ nowych utworach przywołuje zupełnie inne myśli. „Pewne rzeczy się wyostrzają” albo okazuje się, że wcześniej „,człowiek się niepotrzebnie za głęboko zastanawiał, rozwodził nad czymś" mniej istotnym, zamiast skupić się na sprawach ważniejszych. Jak dodaje, „zmieniamy się, świat się zmienia i na nas wpływa, i zmienia się postrzeganie". 
Według Tomasza Swobody świadomość tego, że narracja jest rozpoznaniem i - co ważniejsze - ciągłym nadawaniem sensu, przejawiał w XIX wieku Gérard de Nerval. Jak tłumaczy Swoboda (2012: 3), dla francuskiego pisarza, „[w kontekście życia, któremu] opowiadanie chce nadawać sens, można mówić tylko o próbach wciąż ponawianych, nigdy niespełnionych". W kolejnym stuleciu podobną myśl - podzielaną przez pisarkę - wyraził Paul Ricoeur, według którego powieść fikcyjna - rozumiana jako historia stworzona, lecz niekoniecznie mówiąca nieprawdę - prowadzi do życia, ponieważ proces budowania opowieści nie jest nigdy dopełniony w tekście; za każdym razem dopełnia się po stronie czytelnika. Jak parafrazuje tę myśl Dariusz Czaja, ,"sens opowieści pojawia się na przecięciu świata tekstu i świata czytelnika" (Czaja 2002: 13).

$\mathrm{Z}$ kolei dla Pani Walerii sens pisarstwa "tkwi w dowolności interpretacji”. Czując potrzebę napisania czegoś, często odkrywa głębszą myśl czy wartość swojego utworu $\mathrm{w}$ momencie tworzenia lub po jego powstaniu. Jak mówiła: "zawsze zdaję się unieść tej fali swojej i co z tego wychodzi, to nigdy nie jestem pewna". Porównuje własny sposób tworzenia do procesu malarskiego Zdzisława Beksińskiego, który - jak dowiedziała się z jego biografii - w trakcie pracy nigdy nie planował ostatecznej formy obrazu9. Jednocześnie przyznała:

Ja długo chodzę z jakimś tematem, który dojrzewa we mnie i ja sobie myślę, co by z tego mogło wyniknąć. To jest takie ziarno, które dopiero trzeba zasadzić. Ono musi kiełkować, musi się rozrastać. Aż przychodzi dzień, kiedy ja siadam i ja piszę. Nie powiedziano, że napiszę wszystko od razu, ale tam do pewnego stopnia piszę i wiem, że to skończę.

Kiedy rozmawiałyśmy na temat odbierania i interpretowania literatury, stwierdziła, że „ludzie nie znajdując sensu, odrzucają książkę, ale to nie znaczy, że ona nie ma sensu, tylko jest on zakamuflowany". Jego odnalezienie zależy od "bystrości umysłu i oczytania". Jej zdaniem znakomicie obrazują to przytoczone podczas jednej z rozmów słowa Edwarda Halla, autora pracy Ukryty wymiar:

Malowidła nie mogą bezpośrednio odtworzyć smaku czy zapachu owoców, dotyku i powierzchni poddającego się ciała czy tej szczególnej nuty w głosie niemowlęcia, która powoduje, że w piersiach matki zaczyna wzbierać mleko. Ale zarówno język, jak malarstwo symbolizują takie rzeczy; niekiedy aż tak skutecznie, że prowadzą do reakcji pokrewnych reakcjom wywołanym przez bodźce oryginalne. Jeśli tylko artysta jest dość utalentowany, a odbiorca należy do tej samej kultury, to potrafi wypełnić obraz tym wszystkim, co zostało w nim opuszczone (...). Celem artysty jest zniesienie przeszkód pomiędzy odbiorcami a faktami, które odtwarza (Hall 2005: 105-106).

Dystans między zapisem a tym, o czym on traktuje - a więc omawiany wcześniej problem przekładu myśli czy mowy na tekst pisany - ujawnia się w poezji

9 Malarskie porównania pojawiają się w jej wypowiedziach bardzo często, ponieważ jak sama pisze: „maluję myśli, maluję słowa, maluję przeżyć pejzaże” (Prochownik, Kolory wyobraźni). 
Pani Walerii. I to właśnie do tej formy swej twórczości odnosi ona słowa etnologa. W niej dostrzega "ukryty wymiar", czyli to, "co zostało pominięte" w utworze, a co czytelnik bądź słuchacz "może sobie dopowiedzieć, jeżeli [nadawca i odbiorca] nadają na tych samych falach”. Jak mówi: „[pisząc], nie poda się wszystkiego na talerzu". Sama nieustannie szuka, opisuje to, czego ostatecznie wypowiedzieć się nie da. Ale „,jeżeli chodzi o to [poszukiwanie], to ja miałam na myśli poezję, bo jeżeli proza, to jest całkowicie inna gałąź twórczości" - tłumaczyła. Jako kontrargument dla tych słów można uznać fragment przywoływanego Fajdrosa:

Ten, co myśli, że sztukę w literach zostawia, i ten, co ją chce z nich czerpać, jak gdyby z liter mogło wyjść coś jasnego i mocnego, to człowiek bardzo naiwny (...). Myśli, że słowa pisane coś więcej potrafią jak tylko przypomnieć człowiekowi, który rzecz samą zna, to, o czym pismo traktuje (Platon 2000: 34).

Pisarka widzi w tych słowach ważną „samokrytykę". Jak mówiła: „To jest właściwie prawda, pod pewnymi względami. Bardzo zawiłe, ale prawdziwe". Jednocześnie czuje, że ta zgoda zaprzecza jej samej. „Co właściwie jest sztuką?" zastanawiała się. Na pytanie, czy nazwałaby nią poezję, odparła: „poezja to moja pierwsza miłość, ona jest najbliższa sercu (...), zawieram w niej nie tylko to, co mnie wzruszyło, ale też to, co zbulwersowało". Gdy rozmawiałyśmy o poezji w większym uogólnieniu - nie odnosząc jej bezpośrednio do twórczości pisarki stwierdziła: „właściwie jest ona sztuką, bo próbuje wszystkie emocje zawrzeć w kilku słowach. W wierszu przekazywane są głębsze emocje niż w opowiadaniu. Poezja ma w sobie coś osobistego - narodziny wiersza to tak, jakbym dziecko urodziła".

Poezja jest dla niej „ciągłym poszukiwaniem”, , „otchłanią bez granic”. Uważa, że w tej dziedzinie twórczości "zawsze jest niedosyt" - "gdybyśmy już uchwycili pewne rzeczy, to tak, jakbyśmy się zatrzymali w miejscu". Jak sama pisze, podobnie jest ze szczęściem: „,szczęściem jest chyba do szczęścia dążenie (...) nam się tylko marzy, bo jakże go rozpoznać? Ma sto różnych twarzy" (Prochownik, Szukam szczęścia). Jednocześnie:

Człowiek, który nie poszukuje, który tylko opisuje przyrodę, to nie jest poeta; on pisze wiersze. Trzeba rozróżnić wiersze... i poezję... To są dwa całkowicie odrębne jakby gatunki twórczości (...). Bo wiersze to są na przykład takie rymowanki, coś całkiem prostego, jakby opowieść rymowana. A poezja... Poezja to jest coś głębszego. Coś, co mamy do przekazania. Coś, do czego trzeba mieć większą wyobraźnię.

Jak twierdzi, na poezję musi przyjść odpowiedni czas. Nie każdy dzień nadaje się na jej tworzenie. Pisząc, potrzebuje samotności - wówczas spotyka się sama ze sobą. Gdy czuje potrzebę pisania, temat narzuca się sam. Zdarza się również, że parę lat „chodzi z jakimś tematem”, który „ciężko ubrać w słowa” wtedy czuje niedosyt i "ciężar myśli". Natomiast wspomnienia, które układa prozą, przychodzą jej „lekko”, dlatego powstają niemal codziennie. W tym przy- 
padku przekazywanie emocji nie stanowi dla niej trudności, bo - jak stwierdziła za długo już pisze, żeby się z tym borykać. Równocześnie zdaje sobie sprawę $\mathrm{z}$ tego, jak wiele pracy włożyła, by osiągnąć tę łatwość, dlatego też z wielką cierpliwością słucha początkowych prób pisarskich innych osób.

Odnosząc się do kwestii upływu czasu, platoński Sokrates wyraża obawę, że zapisane słowa mogą trafić $\mathrm{w}$ ręce tych, którzy błędnie je zrozumieją, gdyż samo pismo „(...) nie wie, do kogo warto mówić, a do kogo nie" (Platon 2000: 35); nie jest ono w stanie samo się bronić, odpierać niesłusznych ataków. Pisarka uważa, że w tym kontekście „ważne są spotkania z osobą twórcy, która pewne rzeczy naświetla" i pomaga "ukierunkować” odbiorcę. Twierdzi także, że im dłużej żyje i ma do czynienia z pisarstwem, tym bardziej zastanawia się nad każdym wypowiedzianym i napisanym słowem. Jest przekonana, że jej odpowiedzialność w tym względzie rośnie, lecz określenie swojej pracy „profesjonalną" byłoby dla niej „za dużym słowem”. Zdaje sobie sprawę, że jej utwory mogą przetrwać dłużej niż ona sama, dlatego też stara się je dopracować i "uporządkować": „Słowa są trwalsze niż życie człowieka. Trzeba się z tym liczyć. Czy za 50 lat to będzie miało jakąś wartość"? - zastanawiała się, spoglądając na swoje rękopisy.

Pisarka nie tworzy wyłącznie dla siebie:

[Podczas prezentacji gawęd] bardzo ważny jest kontakt z odbiorcą, bo ja wówczas momentalnie mam przed oczami jakąś reakcję ludzi. Ja nie czekam tylko na to, żeby moje wystąpienie się skończyło, ja to przeżywam. Nie ważne czy mówię do dziesięciu ludzi czy do jednej osoby. Ja daję samą siebie. Całą daję. Chcę coś przekazać i to jest dla mnie bardzo ważne, że to nie leci tak o: pies szczeka, wiatr niesie. Że to ma jakąś wartość.

Gdy mówi śtucne ${ }^{10}$ sekwencje, często słychać „ryk na sali”, ale sama jest tak mocno skoncentrowana na tekście, który prezentuje z pamięci, że nie myśli o śmiechu. Uważa, że gdyby jej losy potoczyły się inaczej, być może zostałaby aktorką - "tak czuję scenę".

Podobnie jak Ryszard Kapuściński (2007: 162), wierzy, że pisanie może zmieniać rzeczywistość, dlatego ludzie, którzy piszą, powinni podchodzić do swej pracy z wielką odpowiedzialnością. Wiara ta nie jest jednak bezgraniczna i absolutna, ponieważ interpretacja tekstu zależy w dużej mierze od samego czytelnika czy słuchacza. Chciałaby, „żeby ludzie więcej myśleli, żeby nie byli tacy bezmyślni. Żeby przeżywali życie, a nie przeżuwali". I właśnie te wartości stara się przekazać za sprawą swojej twórczości.

„Nowe czasy, nowe twarze, nowe nazwiska przychodzą. Ale ja wiem... czy to właściwie jest moim celem, żeby pozostawić po sobie jakiś ślad? Co jest tym śladem"? - zastanawiała się. Z jednej strony, publikacje uznaje za "marności świata tego". Pisarstwo jest jej przede wszystkim "potrzebne do życia”. Stara się po prostu "robić swoje - pisać, a jeżeli komuś przy okazji to się podoba, to tylko

10 Śtucne - gwar. śmieszne. 
się mogę cieszyć". Jak twierdzi, nie zabiega o rozgłos, nie goni za akceptacją, nie czuje potrzeby, „żeby komuś czy sobie coś udowodnić”. Na początku pytała własne dzieci o opinię, lecz obecnie rodzina nie śledzi jej literackich przekazów. $Z$ drugiej strony, świadomość, że za sprawą pisarstwa inni ludzie wiedzą o jej istnieniu, jest dla niej ważna:

Gdybym zapisała się w pamięci przyszłych pokoleń, to świadczyłoby, że żyłam owocnie (...). Może ktoś to kiedyś doceni. Na dzień dzisiejszy ja czuję taką potrzebę, więc się realizuję. A co z tego wyniknie, to... Pewno, że bardzo bym tego chciała, żeby móc wreszcie chwycić tę książkę do ręki, żeby móc to zobaczyć, że coś wyszło. To są dzieje mojego życia. Ale gdy nie dojdzie do tego, to przecież nie będę szat rozrywać. Ale chcę uporządkować na wypadek, gdyby teksty miały ujrzeć światło dzienne bez mojej obecności.

Jednocześnie wyjaśniała: „To jest moją potrzebą - ja żyję tym, ja żyję pisaniem tak można powiedzieć".

Jak pisze Michael Foucault (1999: 310), „rola pisania polega na stworzeniu, łącznie z tym, do czego doprowadziła lektura, pewnego «korpusu»". Ten metaforyczny korpus stanowi "ciało tego, kto zapisując rezultaty swej lektury, przyswoił je sobie, a ich prawdę uczynił prawdą własną" (Foucault 1999: 310). Pisarka stara się realizować mądrości, które zapisuje: „to się kłóci z moją osobą, żebym ja coś innego pisała, a coś innego robiła (...). Nigdy nie udaję kogoś, kim nie jestem". Do słów francuskiego myśliciela odnosi się wprost:

"(...) ich prawdę uczynił prawdą własną"... To jest niby prawdziwe stwierdzenie, bo na przykład ja biorę do jakiegoś opowiadania - nie zawsze jest to autobiografią - wątek czyjegoś życiorysu. A resztę sobie dopowiadam. Te losy tego człowieka są oparte na mojej wyobraźni, a jego życie się mogło inaczej potoczyć. Jest to prawda moja (...). To się staje treścią mojego życia. To, że się nie czuję wyobcowana, to właśnie przez to pisanie (...). Nigdy nie czuję, że jestem sama, bo mam ten świat wyobraźni.

Pisarka zbiera w myślach najważniejsze, a także codzienne doświadczenia, spostrzeżenia i przeżycia.

I dlaczego ja wygrzebuje takie dawne sprawy? Wygrzebuję, bo tym dawniej żyła polska wieś. To było na porządku dziennym (...). Świat się bardzo zmienił, szczególnie się zmieniła wieś (...). Wzięta z życia wiedza jest częścią naszej kultury, [o której] trzeba pamiętać i ocalić od zapomnienia na podobnej zasadzie jak na przykład pamięć o powstaniach.

Równie ważne jest dla niej to, by "pokazać to upodlenie kobiet” i sytuację kobiet w czasach jej młodości, gdy „mężczyzna był na uprzywilejowanej pozycji”. Jak wspominała, panowało wówczas przekonanie, zgodnie z którym ,jak się baby nie bije, to jej wątroba gnije", dlatego mawiano, że "trzeba kobietę bić przynajmniej raz na tydzien". I chociaż dawniej - jak wyjaśniała - nie była „na 
swoim miejscu”, bo ówczesne zajęcia nie były "treścią" jej życia, to warto ukazać specyfikę tamtych lat: „żeby kobiety nie tylko dostrzegały te zmiany i potrafiły je docenić, ale by miały świadomość, że wówczas same ten los swój potęgowały, bo tych mężczyzn się tak hołubiło. Przekazywały to kolejnemu pokoleniu, dlatego nie można winić samych mężczyzn. Kobiety były bierne, poddawały się temu" podobnie jak bohaterka wiersza Życiowa rola (Prochownik 2010: 4):

\author{
(...) Gra rolę szczęśliwej \\ W teatrze jedynego aktora (...) \\ „Gdy maska opadnie" \\ Staje się zwyczajnie CZŁOWIEKIEM \\ Który strawił życie \\ $\mathrm{W}$ roli kobiety
}

\title{
Zakończenie
}

Czym zatem jest pisarstwo dla Walerii Prochownik? Jest ono próbą przybliżenia i poznania otaczającej rzeczywistości, szukaniem w niej "czegoś swojego", lecz także stawaniem wobec tego, czego się nie podziela czy nie pochwala. Pisanie pozwala jej nieustannie tworzyć własną tożsamość, poznawać własne miejsce $\mathrm{w}$ świecie - w ten sposób stając się przede wszystkim „pracą nad sobą". Życie i pisanie Pani Walerii stanowią nierozerwalną jedność. Pisarstwo kreuje jej osobę i charakter w takim samym stopniu, w jakim jej osobowość wpływa na kształt tekstów i opowieści. To ciągły proces dialogicznego poznawania siebie poprzez innych i innych poprzez siebie - rozumienie świata w odpowiedzi na innych, które „musi być wciąż na nowo wypowiadane” (Czaja 2002: 12).

Jak zauważyła pisarka, przed naszymi spotkaniami nie myślała nad tymi kwestiami:

Nigdy bym sobie pewnych pytań nie zadała, gdyby nie te twoje. [Teraz] na nowo przeżywam wartość tego, co przeżyłam (...). Miałam sposobność spojrzenia na tę moją drogę twórczą, cofnąć się wstecz i innymi oczami spojrzeć na tę rzeczywistość (...). Pojęłam, ile to dla mnie znaczyło. To był sens mojego życia, który był dla mnie zamknięty.

Zarówno dla pisarki, jak i dla mnie, nasze rozmowy nie były poszukiwaniem owego sensu, lecz raczej jego tworzeniem. Chcąc w zrozumiały sposób opowiedzieć mi o sobie, musiała nie tylko zinterpretować własne podejście do pisarstwa, ale także spojrzeć na nie $\mathrm{z}$ dystansu. W pewnym momencie zaczęła wyprzedzać moje dociekania i sama problematyzowała poszczególne kwestie. Robiła to w sposób, który wcześniej charakterystyczny był tylko dla mnie.

Michaił Bachtin dowodził, że w dialogu „,każde słowo wyraża «kogoś» w stosunku do «kogoś innego». W słowie nadaję sobie obiektywny kształt z punktu widzenia kogoś innego" (cyt. za: Czaplejewicz 1983: 19). Inaczej mówiąc, jak tłumaczy poglądy rosyjskiego myśliciela Eugeniusz Czaplejewicz: 
(...) w człowieku nie ma wewnętrznego suwerennego terytorium, w całości jest on zawsze na granicy; zaglądając do swego wnętrza, patrzy w oczy innego lub oczami innego (...). Słowo ma naturę społeczną, jest aktem dwustronnym i wspólnym obszarem lub strefą graniczną między rozmówcami (Czaplejewicz 1983: 15, 19).

To metaforyczne usytuowanie pomiędzy światami dotyczyło także mojej sytuacji poznawczej. Nie tylko musiałam interpretować to, co mówiła mi pisarka, ale także przekładać nasze doświadczenia na formę pisaną, która kształtowała się przede wszystkim w odpowiedzi na "to-co-już-powiedziane" (Foucault 1999: 319), tworząc w ten sposób kolejne „objaśnienia objaśnień” (Geertz 2003: 40), zależne również od moich pisarskich (nie)umiejętności.

Jak zauważyła pisarka, różni nas wiek, sposób wychowania oraz fakt, że ja jestem studentką, a ona "prostą, wiejską kobietą". Dodałabym do tego moją nieznajomość żywieckiej gwary. Stąd też naszą postawę wobec siebie nawzajem musiała charakteryzować gotowość do uczenia się, które - zdaniem Emmanuela Lévinasa (1998: 42) - „przychodzi z zewnątrz i przynosi mi więcej, niż sam zawieram”. Także według Bachtina (1983b: 233) „aktywność poznającego łączy się z aktywnością tego, który się odkrywa (dialogowość), a umiejętność poznania - z umiejętnością wyrażania siebie". W przypadku naszych spotkań wiedza rodziła się właśnie w sposób zdarzeniowy ${ }^{11}$. Pod wpływem niektórych pytań pisarka odkrywała kolejne znaczenia wspólnie omawianych myśli, zauważając, że przed rozmowami inaczej je interpretowała. Nie powodowało to jednak przemieszania czy zatarcia naszych zdań i ocen, ponieważ w dialogu każda strona "zachowuje swoją jedność i jawną całościowość, przy czym wzajemnie wzbogacają się" (Bachtin 1983a: 370).

W tym kontekście warto przytoczyć inny - wymieniony przez Lassitera zarzut wobec etnograficznej współpracy: „przyczynia się do nieuprawnionego mieszania naukowości i potoczności, czyli dwóch zupełnie odmiennych poziomów dyskursu" (zob. Pietrowiak 2014: 32). Pojawia się tu jednak pytanie: o czym zatem świadczy owa naukowość, która jednocześnie tak ostro odgradza się od przedmiotu swojego namysłu? Moim zdaniem konfrontacja - która jest czymś zdecydowanie różnym od dowolnego przemieszania - tych dwóch światów otwiera szerokie pole do rozważań na temat akcentowanej przez Lassitera (2005) „przepaści pomiędzy antropologią a społeczeństwami, które studiujemy".

Uważam, że zderzenie zaproponowanych przeze mnie naukowych i filozoficznych ocen na temat natury pisarstwa z wypowiedziami Pani Walerii pozwoliło mi dosyć obrazowo przedstawić odpowiedź na postawione na wstępie pytanie. Jednocześnie ukazało moje przedwczesne zinterpretowanie niektórych poglądów mojej rozmówczyni, co wpłynęło na zamknięcie naszych rozważań w obszarze

${ }^{11}$ W tym kontekście interesujące wydaje się, że - jak zauważył Ong - „hebrajskie określenie dābār znaczy «słowo» oraz «zdarzenie»". Dodatkowo ten sam filozof i historyk przytacza również spostrzeżenie Bronisława Malinowskiego, według którego „dla ludów "prymitywnych» (oralnych) język jest sposobem działania, a nie odpowiednikiem myśli” (Ong 2003b: 191-192). 
jednego - wybranego $\mathrm{w}$ dużej mierze na zasadzie opozycji do poprzednich wypowiedzi pisarki - aspektu.

Czytanie czy słuchanie opowieści innych ludzi staje się twórczym pisaniem, kreowaniem własnego - odmiennego, lecz równoprawnego - sensu lektury (Burzyńska 2006: 299-316). Doświadczanie rzeczywistości nie przynosi jedynej, niepodważalnej prawdy, lecz wiedzę cząstkową, która poprzez konfrontację z doświadczeniami innych może pogłębiać dorobek dotychczasowej wiedzy, otwierać nowe drogi poznania, zachęcać do dalszych poszukiwań. Mimo to Marcin Brocki krytykuje etnografię opartą na współpracy ${ }^{12}$.

Na końcu tego planu zaangażowania informatora nie ma nic - nie może przecież wiedzieć, do czego taka interakcja prowadzi, a przypuszczenie, że do wygenerowania wspólnej wiedzy (czym miałaby ona być?), jest niczym nieuzasadnionym pragnieniem, którego wcale nie muszą oboje pożądać" (Brocki 2013: 12-13).

Zgadzam się, że istnieje taka ewentualność, jednak nie oznacza ona konieczności - wszak "nie muszą pożądać” nie znaczy: „nie mogą", „, nie mają szans”, "nie warto próbować". Być może ten rodzaj podejścia do badań nie sprawdza się we wszystkich przypadkach etnograficznego spotkania, lecz według mnie bezzasadne jest zakładać, że nie może ono wypływać z charakteru nawiązanych $\mathrm{w}$ terenie relacji. Potwierdzeniem tego są słowa Pani Walerii, która podsumowując nasze spotkania, stwierdziła:

Nie czułam dystansu, że jesteś studentką, a ja prostą kobietą, ale że mamy wspólne priorytety, które się dla nas liczyły. To jest bardzo ważne, jak mnie ktoś postrzega, ponieważ ja mogę mieć całkiem inne spojrzenie na pewne rzeczy (...). Ważne, że śledzę to, co o mnie piszesz. Pewne rzeczy, którymi nie chcę się dzielić, nie zostaną napisane. Wolę mieć wgląd.

Czym miałaby być wiedza, o którą pyta Brocki? Według mnie nie musi być ona dokładnie określona przez badacza, tak samo jak nie musi być ostatecznie podzielana przez rozmówców. Ważne, aby dążyć do jej ukazania, uwzględniając przy tym całą jej złożoność, różnorodność i sprzeczność.

12 Brocki używa określenia „etnografia współpracująca”. 


\title{
Postscriptum
}

\section{Rozmowy}

Ewie $H^{13}$

\author{
Te kilka spotkań \\ usiłuje z przepaści lat \\ wydobyć to co łączy \\ lecz tok rozważań \\ nie zmierza do przystani \\ tyle nie dopowiedzianych myśli \\ krąży wokół nas \\ są nieuchwytne niczym czas - \\ Do wspólnego mianownika \\ podążając bezwiednie \\ lecz z plątaniny sprzeczności \\ co rusz wyłania się niewiadoma \\ bo przepaść lat \\ inny świat \\ wciąż mąci czystą wodę \\ to walka $\mathrm{z}$ wiatrakami \\ nie poskładasz mojego życia \\ na twoje podobieństwo... \\ To tylko przestroga \\ ażeby ocalić szczery uśmiech \\ gdy skończy się film \\ o mnie \\ o Tobie \\ o nas!
}

Podczas naszego ostatniego, sierpniowego spotkania Pani Waleria nie czuła potrzeby szczegółowego komentowania mojego tekstu, ponieważ - jak powiedziała - wszystko przedstawiłam po jej myśli. Była nieco zaskoczona, że tak wiele miejsca poświęciłam jej „osobie jako człowiekowi”, lecz nie oceniała tego negatywnie. Spodziewała się, że skoncentruję się jedynie na jej „twórczości”. Jednocześnie zauważyła:

Nie ujęłaś kompletnie spraw mojej głębokiej wiary. Ale to jest twoja sprawa. Czy mi tego zabrakło? Nie, bo to jest indywidualna sprawa każdego człowieka. Moje życie, ono się teraz toczy tak, że ja dzielę dzień na twórczość i na modlitwę. To są dwie jakby zespolone ze sobą sprawy. Że ty o tym nie piszesz, to mi to absolutnie nie przeszkadza. To jest moja prywatna sprawa (...), coś tak osobistego, że jak cię tylko to nie razi, to jest dobrze.

13 Utwór powstał przed przeczytaniem przez pisarkę mojego tekstu, lecz z myślą o zamieszczeniu go w publikacji. 
Gdy spytałam o opinię pisarki na temat zakończenia tekstu, stwierdziła: „nie czuję się kompetentna, żeby komentować naukowe myśli". Następnego ranka powiedziała jednak z uśmiechem: „pojęłam, o co ci chodzi w zakończeniu. Jestem pełna podziwu, jak umiejętnie prowadziłaś rozmowy, żeby się nie zdradzić, o co ci naprawdę chodzi". Wyjaśniłam, że w trakcie spotkań nie wiedziałam, dokąd nas one doprowadzą - dopiero wzajemne, stopniowe poznawanie i próba opisania tego procesu nadawała kształt myślom i wnioskom. Odparła:

Kształtujemy swoje myśli, swoją osobowość przez te rozmowy. Jednak to jest długotrwały proces. Teraz rozumiem, dlaczego spotykałyśmy się tyle razy. Chcąc siebie poznać, jakby zajrzeć $\mathrm{w}$ to swoje wnętrze, myśmy musiały ze sobą ileś tych rozmów przeprowadzić (...). Ale chociażby powstało jeszcze raz tyle tekstu, to tematu i tak dogłębnie nie rozstrzygniemy.

"Odkrycie" sensu końcowej części tekstu, które nie pozwoliło jej szybko zasnąć poprzedniego wieczoru, doprowadziło do kolejnych rozmyślań:

Co się stało ze mną w trakcie tych rozmów? Ja się stałam innym człowiekiem. Dowartościowałam się. Zrozumiałam, że mam coś do powiedzenia. Zaczęłam bardziej analizować, z kim się zadaję, co robię. Ciekawa jestem, w jakim kierunku po tym odkryciu twórczość moja pójdzie, jak będzie wyglądała. To się okaże. To jest dopiero przede mną.

Na koniec poprosiła, abym zamieściła w tekście jej pisemny komentarz, co też czynię, oddając mu jednocześnie „ostatnie słowo":

Na życiowej drodze dane mi było spotkać wielu ludzi. Różna była moja reakcja na te spotkania. Pośród osób, które nie tylko że nie wzbudziły zainteresowania, wręcz "odpychały" od siebie, spotykałam też bratnie dusze. Pani Ewa ${ }^{14} \mathrm{z}$ pewnością do nich należy. Że nasza znajomość zaowocuje czymś tak ważnym, to tego z pewnością nie zaplanowałyśmy. Sądzę, że atutem naszej, ośmielę się tak to nazwać, współpracy jest spontaniczność. Przy czym nastąpiło też wzajemne ubogacenie naszych osobowości. Śmiem stwierdzić, że różnica pokoleń jest mocno przejaskrawiona. Nie odczuwałam jej i od chwili poznania żadna bariera nie powstawała między nami, wręcz przeciwnie. Z pewnością nasza znajomość ubogaciła moje wnętrze i pozwoliła mi nareszcie uwierzyć w siebie. Prawdziwe jest stwierdzenie, że uczymy się do śmierci. Wiele się nauczyłam, a oprócz tego zrodziło się między nami coś pięknego - szczera przyjaźń. Oparta ona jest na wzajemnym zrozumieniu i akceptacji. Pozostaje mi tylko życzyć p. Ewie, ażeby na swojej życiowej drodze spotkała wielu ciekawych ludzi, którzy z pewnością nadadzą sens Jej życiu.

14 Pani Waleria, mimo że zwraca się do mnie po imieniu, uznała, że w powyższym tekście - ze względu na jego naukowy kontekst - powinna zamieścić formę, która jej zdaniem będzie w tym przypadku „oznaką szacunku”. 


\section{Literatura}

Bachtin, M. (1983a). Kierować się odwagą. Przeł. D. Danek. W: E. Czaplejewicz, E. Kasperski (red.). Bachtin. Dialog - Jezzyk - Literatura (s. 364-370). Warszawa: Państwowe Wydawnictwo Naukowe.

Bachtin, M. (1983b). O metodologii badań literackich i humanistycznych. Przeł. S. Zapaśnik. W: E. Czaplejewicz, E. Kasperski (red.). Bachtin. Dialog - Jezzyk - Literatura (s. 232-240). Warszawa: Państwowe Wydawnictwo Naukowe.

Brocki, M. (2013). Badania oparte na współudziale, badania w działaniu i etnografia współpracująca - argumenty przeciw. Zeszyty Etnologii Wrocławskiej, 2(19), 5-16.

Burzyńska, A. (2006). Anty-teoria literatury, Kraków: Universitas.

Czaja, D. (2002). Życie czyli nieprzejrzystość. Poza antropologię - kultury. Konteksty. Polska Sztuka Ludowa, 56(3-4), 6-22.

Czaplejewicz, E. (1983). Bachtin i jego idee. W: E. Czaplejewicz, E. Kasperski (red.). Bachtin. Dialog - Jezzyk - Literatura (s. 9-26). Warszawa: Państwowe Wydawnictwo Naukowe.

Gąsiorek, J., Juraszek, T. (2011). Słownik gwary żywieckiej. Żywiec.

Geertz, C. (2003). Opis gęsty. W stronę interpretatywnej teorii kultury. Przeł. S. Sikora. W: M. Kempny, E. Nowicka (red.). Badanie kultury. Elementy teorii antropologicznej (s. 35-58). Warszawa: Wydawnictwo Naukowe PWN.

Figiel, S. i in. (2006). Beskid Żywiecki. Przewodnik. Pruszków: Oficyna Wydawnicza „Rewasz".

Foucault, M. (1999). Sobąpisanie. W: M. Foucault. Szaleństwo i literatura (s. 303-319). Warszawa: Fundacja Aletheia.

Futoma, A., Cebrat, J. (2006). Bogactwo kultury górali żywieckich. W górach, 3(9). http:/ / www.wgorach.com/?id=43182\&locati. [dostęp: 31.03.2015].

Hall, E.T. (2005). Ukryty wymiar. Przeł. T. Hołówka. Warszawa: Muza S.A.

Kapuściński, R. (2007). Lapidarium VI. Warszawa: Czytelnik.

Kastelik-Herbuś A. (2007). Żywieccy Zbójnicy w ludowych opowiadaniach. Literatura Ludowa, 4-5(51), 73-82.

Lassiter, L.E. (2005). The Chicago Guide to Collaborative Ethnography. Chicago - London: University of Chicago Press.

Lévinas, E. (1998). Całość i nieskończoność. Esej o zewnętrzności. Przeł. M. Kowalska. Warszawa: Wydawnictwo Naukowe PWN.

Młodzianowski, L. (2009-2012). Harnasiowy żywot - krótko, zwięźle i na temat. Zbójnicki Szlak. http://www.zbojnickiszlak.pl/index.php?menu=b\&id_menu=145 [dostęp: 01.04.2015].

Nagrody im. Oskara Kolberga "Za zastugi dla kultury ludowej". http://www.nagrodakolberg.pl/181 [dostęp: 21.08.2015].

Niewiadomski, D. (2011). „Kocham ziemię beskidzką miłością wierną” - życie i twórczość Walerii Prochownik. Kultura Ludowa.pl. http://www.kulturaludowa.pl/widok/163/ 2236 [dostęp: 24.07.2015].

Ong, W.J. (2003a). Pismo a struktura świadomości. W: A. Mencwel, R. Sulima, G. Godlewski (red.). Antropologia stowa. Zagadnienia i wybór tekstów (s. 368-380). Warszawa: Wydawnictwa Uniwersytetu Warszawskiego.

Ong, W.J. (2003b). Psychodynamika Oralności. W: A. Mencwel, R. Sulima, G. Godlewski (red.). Antropologia stowa. Zagadnienia i wybór tekstów (s. 191-202). Warszawa: Wydawnictwa Uniwersytetu Warszawskiego.

Pietrowiak, K. (2014). Etnografia oparta na współpracy. Założenia, możliwości, ograniczenia. Przegląd Socjologii Jakościowej, 4(10), 18-37.

Platon (2000). Fajdros. W: Platon. Dialogi (s. 5-37). Gdańsk: Wydawnictwo Tower Press. 
Prochownik, W. (2010). Wcielenia. O kobietach prawie wszystko. Żywiec: Towarzystwo Miłośników Ziemi Żywieckiej, Grupa Literacka "Gronie”.

Prochownik, W. (2002). Johanino krzywda (wspomniyeni z dziecijstwa). W: M. Jurasz (red.). Na góralskich posiadach (s. 22-25). [b.m]: Stowarzyszenie Społeczno-Kulturalne "GROJCOWIANIE" z Wieprza.

Rabinow, P. (2010). Refleksje na temat badań terenowych w Maroku. Przeł. K.J. Dudek, S. Sikora. Kęty: Wydawnictwo Marek Derewiecki.

Rappaport, J. (2013). Poza obserwacją uczestniczącą - etnografia oparta na współpracy jako innowacja teoretyczna. Tematy z Szewskiej, 1(9), 15-37.

Swoboda, T. (2012). Przedmowa. W: G. de Nerval. Śnienie i życie (s. 1-5). Gdańsk: słowo/ obraz terytoria.

Wyka, A. (1993). Badacz spoteczny wobec doświadczenia. Warszawa: Wydawnictwo Instytutu Filozofii i Socjologii PAN.

\section{SUMMARY}

Writing a life out. An ethnographic meeting with Waleria Prochownik a writer from Sporysz district of Żywiec

"What is writing to Waleria Prochownik?" was the leading question for hours of conversation between me and the writer from Żywiec. The following paper is the outcome of our struggle to confront the writer's views and feelings with thoughts of philosophers, historians, ethnologists, and writers I selected about the nature of writing. It is also an attempt to reflect on mutual understanding, following the main assumptions of collaborative ethnography inspired by methodological conceptions of Luke Eric Lassiter and reflections of Anna Wyka about social research through shared experience. The paper is the result of my field research in Żywiec carried out in 2013, 2014 and 2015.

Keywords: writing, collaborative ethnography, Żywiec/Sporysz, Waleria Prochownik, dialogue 